\title{
Favipiravir-Induced Nephrotoxicity in a Patient with COVID-19: a case report
}

\author{
Asmaa Abdelbary ${ }^{1}$, Ahmad Alharafsheh ${ }^{1}$, Afif Ahmed $^{1}$, and Abdulqadir Nashwan ${ }^{1}$ \\ ${ }^{1}$ Hamad Medical Corporation
}

April 25, 2021

\begin{abstract}
This report describes a case of 45 years old male patient who tested positive for COVID-19 presented to the emergency department on March 2021 complaining of fever, cough, runny nose, and shortness of breath. The patient denied any history of nausea or diarrhea who has eventually developed favipiravir-induced nephrotoxicity.
\end{abstract}

\section{Hosted file}

FAV_Case_v0.4.edited.pdf available at https://authorea.com/users/409880/articles/519422favipiravir-induced-nephrotoxicity-in-a-patient-with-covid-19-a-case-report

\section{Hosted file}

Figure 1.pdf available at https://authorea.com/users/409880/articles/519422-favipiravirinduced-nephrotoxicity-in-a-patient-with-covid-19-a-case-report 